\title{
Inactivation of JNK1/2 Promotes Lung Squamous Cell Carcinoma in Lkb1 Deficiency Mice
}

\author{
Ji Ying Song* \\ Department of Experimental Animal Pathology, The Netherlands Cancer Institute \\ *Corresponding author: Ji-Ying Song, Department of Experimental Animal Pathology The Netherlands Cancer Institute, \\ Plesmanlaan 121, 1066CX, Amsterdam, The Netherlands
}

\begin{tabular}{lll}
\hline ARTICLE INFO & & ABSTRACT \\
Received: & & Citation: Ji Ying Song. Inactivation of Jnk1/2 Promotes Lung Squamous Cell Carcinoma in \\
Published: 14,2019 & & Lkb1 Deficiency Mice. Biomed J Sci \& Tech Res 20(5)-2019. BJSTR. MS.ID.003505.
\end{tabular}

\section{Short Communication}

Lung cancer is the leading cause of cancer-associated mortality worldwide. In the last two decades, great efforts were made to search for effective treatments by identifying drug-targetable biomarkers based on multiple levels of genomic and epigenomic investigations. Histologically, lung cancer can be classified as two major subtypes, namely adenocarcinoma (ADC) and squamous cell carcinoma (SCC), together they account for more than $80 \%$ of cases. Although more than $50 \%$ of lung cancers showed a mix of the subtypes indicating a high degree of heterogeneity of these tumors $[1,2]$, the ADC and SCC are shown to possess a distinct pattern of genomic abnormalities $[3,4]$. By mimicking genomic alterations of human cancer in mice, the whole process of tumorigenesis from initial to advanced stages can be dissected and studied in a spatial and temporal manner. Thereby it is possible to recapitulate, validate, and identify new targets for therapeutics. Importantly, the generated mouse models can be applied for testing new therapeutic strategy as well as drug resistance management.

Unlike previous Lung SCC (LSCC) models in which compound mutations and depletions were involved such as $\operatorname{Kras}^{G 12 D} / L k b 1^{\text {loss }}$, Sox $2^{o x} / L k b 1^{\text {loss }}$, or Pten ${ }^{\text {loss }} / L k b 1^{\text {loss }}[5,7]$, Jian Liu et al. were able to show that $L k b 1$ deficiency by itself was sufficient to induce LSCC in 11-14 months after application of $C C S P^{i C r e}$ in $L k b 1^{f / f}$ mice with a penetrance of $32.8 \%$ of LSCC and its initial lesions (Nature Communication, 10:1-16, 2019) [8]. Impressively the process of tumorigenesis was accelerated to 7-8 months when $J n k 1^{d / d} / J n k 2^{-/-}$was combined and a $100 \%$ penetrance of LSCC and its initial lesions was achieved!
In human, LSCC is initiated from epithelial hyperplasia and squamous cell metaplasia in bronchus/bronchiole, followed by dysplasia and carcinoma. Jian Liu et al. succeeded in mimicking this process and demonstrated sequential lesions of hyperplasia, squamous cell metaplasia, and SCC in the large airway of LKb1 deficiency mice. Importantly the lesions recapitulated the characteristics of human LSCC such as expression of $\Delta$ Np63/P63 and CK5 and had a high degree of a positive relationship with human LSCC in transcriptome profiling. Furthermore, in GSEA (Gene Set Enrichment Analysis) the authors identified the JNK1/2 phosphorylation-induced pathway that was the top enriched pathway and was negatively associated with the $L k b 1$ deficiency gene signature.

To address JNK1/2 as major suppressors for Lkb1-dependent LSCC initiation and progression, the authors conducted in vitro and in vivo investigations by ablating JNK1/2 in mLSCC cells and knocking JNK1/2 out in Lkb1 deficiency mice. The results thereby showed increased cell growth in vitro and acceleration of LSCC development with a full penetrance in vivo. In this context, they were able to associate $J n k 1 / 2$ knockout or inactivation with activation of $\Delta N p 63 / p 63$ pathways that led to LSCC initiation and progress. Conversely, Jian Liu et al. utilized JNK1/2 activators such as Anisomycin for pharmaceutical activation of JNK1/2 in mice that resulted in a decrease of expression of $\Delta N p 63 / p 63$ and consequently a lower incidence of LSCC. Thereby they elucidated a negative regulation of JNK1/2 on the Np63/p63 pathway involving in LSCC development. The negative relationship between 
JNK1/2 activation and P63 expression could be clinically relevant for prediction and treatment of LSCC patients when low JNK1/2 phosphorylation level is evident.

As shown by Jian Liu et al. and others [9], high inflammatory responses were present in mouse models of LSCC that resembled the human counterpart. Further investigations in the role of JNK1/2 and its regulation by cytokines will add more insight into the significance of the tumor microenvironment involving in tumor initiation and progress, which may provide new approaches towards LSCC management.

\section{References}

1. Travis WD (2002) Pathology of lung cancer. Clin Chest Med 23: 65-81.

2. Walker S (2008) Updates in non-Small lung cancer. Clin J Oncol Nurs 12: 587-596.

3. Cancer Genome Atlas Research Network. (2014) Comprehensive molecular profiling of lung adenocarcinoma. Nature 511: 543-550.

4. Campbell JD, Alexandrov A, Kim J, Wala J, Berger AH, Pedamallu CS, Shukla SA, Guo G, Brooks AN, Murray BA, Imielinski M, Hu X, Ling S, Akbani R, Rosenberg M, Cibulskis C, Ramachandran A, Collisson EA, Kwiatkowski DJ, Lawrence MS, Weinstein JN, Verhaak RG, Wu CJ, Hammerman PS, Cherniack AD, Getz G, Cancer Genome Atlas Research Network,

ISSN: 2574-1241

DOI: $10.26717 /$ BJSTR.2019.20.003505

Ji Ying Song. Biomed J Sci \& Tech Res

This work is licensed under Creative Commons Attribution 4.0 License

Submission Link: https://biomedres.us/submit-manuscript.php
Artyomov MN, Schreiber R, Govindan R, Meyerson M (2016) Distinct patterns of somatic genome alterations in lung adenocarcinomas and squamous cell carcinomas. Nat Genet 48: 607-616.

5. Ji H, Ramsey MR, Hayes DN, Fan C, McNamara K, Kozlowski P, Torrice C, Wu MC, Shimamura T, Perera SA, Liang MC, Cai D, Naumov GN, Bao L, Contreras CM, Li D, Chen L, Krishnamurthy J, Koivunen J, Chirieac LR, Padera RF, Bronson RT, Lindeman NI, Christiani DC, Lin X, Shapiro GI, Jänne PA, Johnson BE, Meyerson M, Kwiatkowski DJ, Castrillon DH, Bardeesy N, Sharpless NE, Wong KK (2007) LKB1 modulates lung cancer differentiation and metastasis. Nature 488: 807-810.

6. Xu C, Fillmore CM, Koyama S, Wu H, Zhao Y, Chen Z, Herter-Sprie GS, Akbay EA, Tchaicha JH, Altabef A, Reibel JB, Walton Z, Ji H, Watanabe H, Jänne PA, Castrillon DH, Rustgi AK, Bass AJ, Freeman GJ, Padera RF, Dranoff G, Hammerman PS, Kim CF, Wong KK (2014) Loss of Lkb1 and pten leads to lung squamous cell carcinoma with elevated PD-L1 expression. Cancer Cell 25: 590-604.

7. Mukhopadhyay A, Berrett KC, Kc U, Clair PM, Pop SM, Carr SR, Witt BL, Oliver TG (2014) Sox2 cooperates with Lkb1 loss in a mouse model of squamous cell lung cancer. Cell Rep 8: 40-49.

8. Liu J, Wang T, Creighton CJ, Wu SP, Ray M, Janardhan KS, Willson CJ, Cho SN, Castro PD, Ittmann MM8, Li JL, Davis RJ, DeMayo FJ (2019) JNK1/2 represses Lkb1-deficiency-induced lung squamous cell carcinoma progression. Nature Communication 10: 2148.

9. Ferone G, Song JY, Sutherland KD, Bhaskaran R, Monkhorst K, Lambooij JP, Proost N, Gargiulo G, Berns A (2016) Sox2 is the determining oncogenic switch in promoting lung squamous cell carcinoma from different cells of origin. Cancer Cell 30: 519-532.

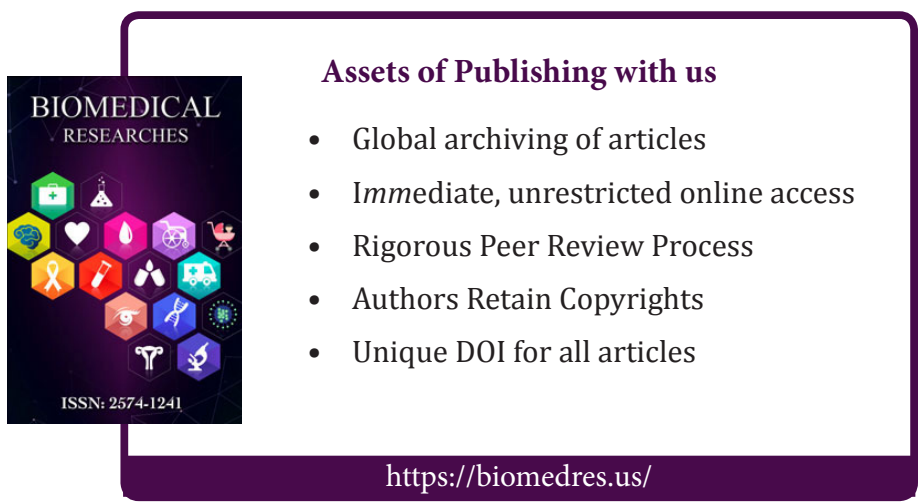

